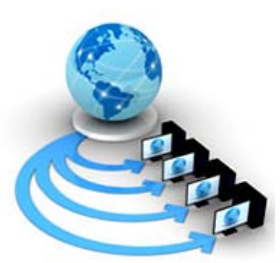

\title{
MOVING TOWARDS AN OUTCOME BASED EDUCATION IN ENGINEERING
}

\author{
Jayashree Agarkhed \\ Professor, Department of Computer Science and Engineering, \\ P.D.A College of Engineering, Kalaburagi, India
}

\begin{abstract}
Education field is facing new numerous challenges to cope with the dynamic demands of the industry. In this direction teaching and learning process framework has undergone rigorous rethink. The development of a new way of learning strategy called outcome based education (OBE) is the rapid transformation made in the modern field today. The need for reformation was identified and the opportunities are highly stretched with huge expectations. The paper discusses the reasons and results for transformations of outcome based education and describe the process of using blooms taxonomy as a tool for educator in assessing and enhancing the one's ability to learn with respect to the set learning objectives.
\end{abstract}

Keywords: OBE, Transformation, Education

\section{INTRODUCTION}

The traditional teaching and learning methods in engineering education are facing greater challenges and failing to fulfill the dynamic industry requirements. This has necessitated frequent curriculum revision has to be performed in order to meet ever-changing requirements of the industry. There are enormous ways of teaching learning process. The OBE is an approach to education in which decisions about the curriculum are driven by the learning outcomes that the students should display at the end of course (subject). Outcome-based learning is learner driven and aimed at achieving outcomes and teacher is facilitator [1]. The development of OBE system provides a new framework for mastery over the learning process [2]. The curriculum stage is the latest phenomenon for the progression and regression by the traditionalists which is acknowledged by administrators and teachers [3]. The common method of assessing the knowledge gained by the students is by the written examination in higher education institutions [4]. Learning outcomes are statements specifying what learners will know or be able to do as a result of a learning activity. Describe a desired condition the knowledge, skills or attitudes required to fulfill a need. Widely accepted Blooms taxonomy gives guidelines in designing reasonable examination questions belonging to various cognitive levels of students. This has emphasized the application of Bloom's taxonomy for preparation of question papers to assess student's performance.

The structure of the paper is organized as follows. Section II discusses the related work on challenges and issues in curriculum design when moving towards OBE. Section III describes blooms taxonomy for educational objectives and learning outcomes. Section IV concludes.

\section{RELATED WORK}

It is evident from most of the study and practices that, whentraditional education technique when transformed into OBE technique, students have become confident significantly.An important framework was designed and developed by Dr. Benjamin S Bloom and Published in 1956, for teachers to focus more on higher order thinking. Bloom's
Taxonomy has provided a basis for ideas which have been used and developed around the world by academicians for the preparation of learning evaluation materials [5].

Blooms taxonomy has set learning objectives for education based outcomes. Different cognitive levels are used for analyzing the student assessment. Automatic analysis system can be used to determine the exact classification in blooms taxonomy [4]. A learning evaluation model for lean training and deployment success is used for lean deployment. The lean learning methods are prepared along with the case studies is presented for learning outcomes [6]. Emphasis can be given on Bloom's taxonomy for preparation of question papers to assess student's performance. Dynamic cognitive process applications of blooms taxonomy for complex software design in cognitive domain are specified [7].

Most of the teachers have their own methodology to describe any concept with the help of illustrations, demonstrable examples etc.. They may follow their own way of teaching delivery method to reach considerably to the students. Due to varying competencies of students new techniques in teaching learning process has to be incorporated such as collaborative learning, forming pairs of senior-junior, group discussions, etc. Following are the challenges faced and requirements found while moving towards outcome based education.

- Fine tuning of the academic curriculum to meet the ever dynamic requirements of the industry.

- Need of move from curriculum based education approach to outcome based education approach.

- Need of transition from teacher centered approach to student centered approach

- It is important to keep in mind how to deliver the topics rather than making chapters while framing syllabus.

- In order to develop models, the usefulness of the course to student is to be rigorously analyzed and if necessary changes are to be incorporated.

- Life long learner and self learner: As the syllabus what the student learn, may become obsolete within 2-3 years.

- Emphasis has to be given on Process oriented approach rather than Person oriented approach. 


\section{BLOOM'S TAXANOMY}

Blooms taxonomy can be considered as basis for Learning Outcomes. The figure 1 shows the three learning domains identified by Blooms et.al are overlapped with each other covers all human aspects. Each of the three domains of
Bloom's Taxonomy is divided into levels of learning developments and these categories are ordered in degree of difficulty. Lowest levels contribute foundational skills and knowledge that are required for learning at higher level. An important premise of Bloom's Taxonomy is that each level must be mastered before progressing to the next [8].

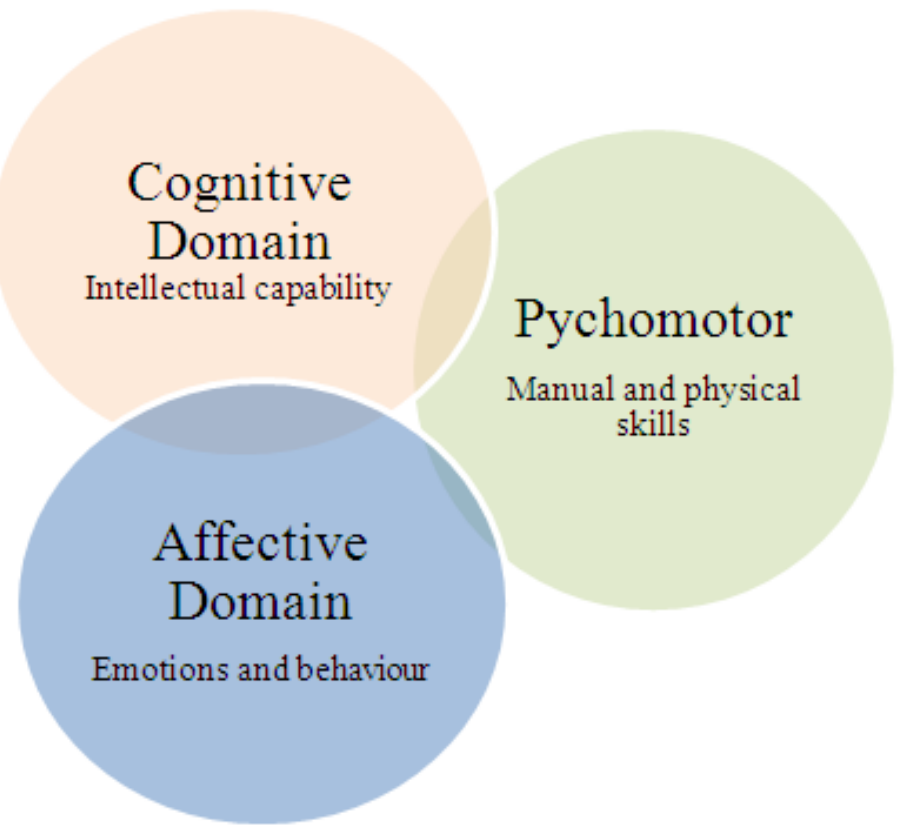

Figure 1. Learning Domains

- $\quad$ Cognitive domain

Blooms et.al has shown that the thought process can be categorized into six classes of competencies that student display. The blooms taxonomy is shown in figure 2 where the lower levels become foundation for the higher levels.The Bloom's taxonomy process is ordered in such a way that the lowest level is the simplest form of recognition, while the highest level built on lower levels involves more complex form of cognitive skill [3]. By providing a hierarchy of levels, this taxonomy can assist teachers in designing assessment framework to measure the students learning ability and making teaching method, innovative and adaptive to students competencies and enhancing the same..
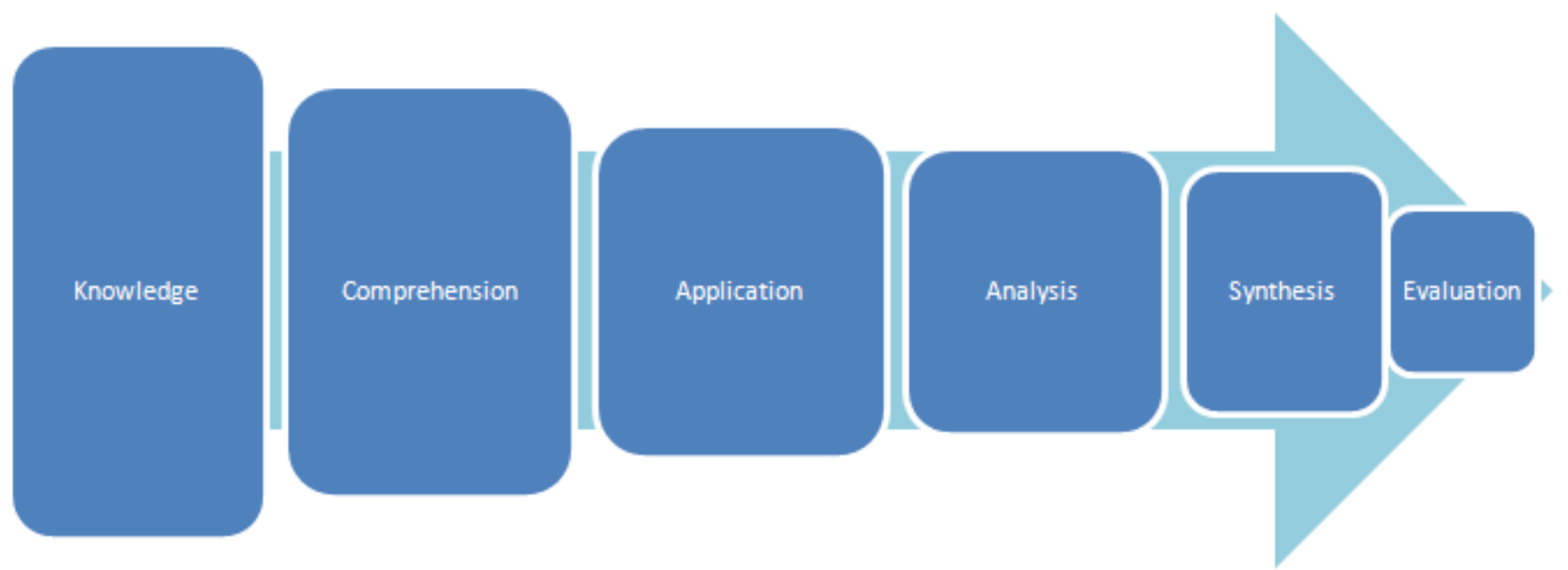

Figure 2.A Bloom's Taxonomy of Educational Objectives for Learning, Teaching and Assessing

Cognitive domain is designed to verify student's cognitive quality in written examination. Following are the various levels of blooms taxonomy which are the basis for learning outcomes. The blooms taxonomy for educational objectives for teaching learning, and assessing is shown in figure 3 


\begin{tabular}{|c|c|c|c|}
\hline $\begin{array}{l}\text { Level } \\
\text { Number }\end{array}$ & $\begin{array}{l}\text { Name of } \\
\text { Blooms Level }\end{array}$ & Required Depth of Ability & Action Words to assess the students cognitive skills \\
\hline I & Knowledge & $\begin{array}{l}\text { Remember or memorize facts, } \\
\text { terms, basic concepts or recall the } \\
\text { knowledge they learnt before. }\end{array}$ & $\begin{array}{l}\text { list, define, tell, describe, identify, show, label, collect, } \\
\text { examine, tabulate, quote, name, who, when, where, what, } \\
\text { why, when, omit, where, which, choose, find, how, define, } \\
\text { spell, match, name, relate, select, observation and recall of } \\
\text { information, knowledge of dates, events, places, } \\
\text { knowledge of major ideas, mastery of subject matter. }\end{array}$ \\
\hline II & Comprehension & $\begin{array}{l}\text { Understand and restate or describe } \\
\text { a learnt concept using their own } \\
\text { words or explanation are the } \\
\text { concepts of this level. } \\
\text { Demonstrate understanding of } \\
\text { facts and ideas by organizing, } \\
\text { comparing, translating, } \\
\text { interpreting, giving descriptors and } \\
\text { stating main ideas. }\end{array}$ & $\begin{array}{l}\text { Summarize, Describe, Interpret, Contrast, Predict, } \\
\text { Associate, Distinguish, Estimate, Differentiate, Discuss, } \\
\text { Extend, Compare, Demonstrate, Explain, Illustrate, Infer, } \\
\text { Outline, Relate, Rephrase, Translate, Show, Classify }\end{array}$ \\
\hline III & Application & $\begin{array}{l}\text { Students' skill in using the theories } \\
\text { learnt to solve new problems in } \\
\text { new situations by applying } \\
\text { acquired knowledge, facts, } \\
\text { techniques and rules in a different } \\
\text { or new way }\end{array}$ & $\begin{array}{l}\text { Apply, Demonstrate, Calculate, Complete, Illustrate, Show, } \\
\text { Solve, Examine, Modify, Relate, Change, Classify, } \\
\text { Experiment, Discover, Build, Choose, Construct, Develop, } \\
\text { Interview, Make Use Of, Organize, Experiment With, Plan, } \\
\text { Select, Solve, Utilize, Model, Identify }\end{array}$ \\
\hline IV & Analysis & $\begin{array}{l}\text { Examine and divide the } \\
\text { information into parts by } \\
\text { identifying motives or causes } \\
\text { Seeing patterns, organization of } \\
\text { parts, recognition of hidden } \\
\text { meanings and identification of } \\
\text { components. }\end{array}$ & $\begin{array}{l}\text { Analyze, Separate, Order, Explain, Connect, Classify, } \\
\text { Arrange, Divide, Compare, Select, Infer, Categorize, } \\
\text { Contrast, Discover, Dissect, Examine, Inspect, Simplify, } \\
\text { Survey, Test For, Distinguish, List, Distinction, Theme, } \\
\text { Relationships, Function, Motive, Inference, Assumption, } \\
\text { Conclusion, Take Part In }\end{array}$ \\
\hline $\mathrm{V}$ & Synthesis & $\begin{array}{l}\text { ability to put parts together } \\
\text { Compile information together in a } \\
\text { different way by combining } \\
\text { elements in a new pattern or } \\
\text { proposing alternative solutions. } \\
\text { Use old ideas to create new ones, } \\
\text { generalize from given facts, relate } \\
\text { knowledge from several areas, } \\
\text { predict, draw conclusions. }\end{array}$ & $\begin{array}{l}\text { combine, integrate, modify, rearrange, substitute, plan, } \\
\text { create, design, invent, what if, compose, prepare, } \\
\text { generalize, rewrite, build, choose, combine, compile, } \\
\text { compose, construct, develop, estimate, formulate, imagine, } \\
\text { make up, originate, predict, propose, solve, solution, } \\
\text { suppose, discuss, modify, change, original, improve, adapt, } \\
\text { minimize, maximize, theorize, elaborate, test, happen, } \\
\text { delete }\end{array}$ \\
\hline VI & Evaluation & $\begin{array}{l}\text { Present and defend opinions by } \\
\text { making judgments about } \\
\text { information, validity of ideas or } \\
\text { quality of work based on a set of } \\
\text { criteria. } \\
\text { Compare and discriminate between } \\
\text { ideas, assess value of theories, } \\
\text { presentations, make choices based } \\
\text { on reasoned argument, verify value } \\
\text { of evidence, recognize subjectivity }\end{array}$ & $\begin{array}{l}\text { assess, decide, rank, grade, test, measure, recommend, } \\
\text { convince, select, judge, explain, discriminate, support, } \\
\text { conclude, compare, summarize, award, choose, conclude, } \\
\text { criticize, decide, defend, determine, dispute, evaluate, } \\
\text { judge, justify, measure, compare, mark, rate, recommend, } \\
\text { rule on, select, agree, appraise, prioritize, opinion, interpret, } \\
\text { explain, support importance, criteria, prove, disprove, } \\
\text { assess, influence, perceive, value, estimate, deduct. }\end{array}$ \\
\hline
\end{tabular}

Figure 3: Blooms Taxonomy at Cognitive domain 
- Affective domain

The Affective domain is related with feelings, emotions and behavior. The affective domains of blooms taxonomy are divided into various levels of learning development which are ordered in the degree of difficulty. The affective domain taxonomy is shown in figure 4.

\begin{tabular}{|c|c|c|c|c|}
\hline $\begin{array}{l}\text { Level } \\
\text { Number }\end{array}$ & $\begin{array}{l}\text { Name of Blooms } \\
\text { Level }\end{array}$ & $\begin{array}{l}\text { Required Depth of } \\
\text { Ability }\end{array}$ & Example & $\begin{array}{l}\text { Action Words to assess the } \\
\text { students cognitive skills }\end{array}$ \\
\hline I & $\begin{array}{l}\text { Receiving } \\
\text { Phenomena }\end{array}$ & $\begin{array}{l}\text { Awareness, } \\
\text { willingness to hear, } \\
\text { selected attention. }\end{array}$ & $\begin{array}{l}\text { Listen with respect, remember } \\
\text { names }\end{array}$ & $\begin{array}{l}\text { Asks, chooses, follows, } \\
\text { identifies, locates, names, } \\
\text { points to, selects, Replies }\end{array}$ \\
\hline II & $\begin{array}{l}\text { Responding to } \\
\text { Phenomena }\end{array}$ & $\begin{array}{l}\text { Learner's active } \\
\text { participation, } \\
\text { willingness to respond }\end{array}$ & $\begin{array}{l}\text { Participates in discussions, gives a } \\
\text { presentation, practices safety rules }\end{array}$ & $\begin{array}{l}\text { answers, assists, conforms, } \\
\text { discusses, labels, } \\
\text { presents, recites, reports }\end{array}$ \\
\hline III & Valuing & $\begin{array}{l}\text { The worth the learner } \\
\text { attaches to an object, } \\
\text { phenomena or } \\
\text { behavior. Acceptance } \\
\text { of others, } \\
\text { commitment. }\end{array}$ & Cultural sensitivity & $\begin{array}{l}\text { demonstrates, differentiates, } \\
\text { invites, initiates, justifies, } \\
\text { proposes, shares }\end{array}$ \\
\hline IV & Organization & $\begin{array}{l}\text { Prioritizes, contrasts } \\
\text { different values, } \\
\text { resolves conflicts. } \\
\end{array}$ & $\begin{array}{l}\text { Accepting responsibility. Accepts } \\
\text { professional, ethical standards, time } \\
\text { management. }\end{array}$ & $\begin{array}{l}\text { adheres, alters, compares, } \\
\text { combines, defends, formulates, } \\
\text { integrates, modifies, }\end{array}$ \\
\hline V & $\begin{array}{l}\text { Internalizing } \\
\text { (characterization) }\end{array}$ & $\begin{array}{l}\text { Behavior consistent } \\
\text { with coherent value } \\
\text { system }\end{array}$ & $\begin{array}{l}\text { shows self-reliance in work, } \\
\text { cooperative in group activities, } \\
\text { problem solves, accepts } \\
\text { info.contrary to beliefs. }\end{array}$ & $\begin{array}{l}\text { discriminates, influences, } \\
\text { modifies, qualifies, questions, } \\
\text { revises, verifies }\end{array}$ \\
\hline
\end{tabular}

Figure 4: Blooms Taxonomy at Affective domain

- Psychomotor domain

The psychomotor domain is related with manual and physical skills in to effect, ie., skills, or 'do'. This category of blooms taxonomy is the learning at the higher level which is dependent for attaining knowledge and skills at the lower levels. The psychomotor domain taxonomy is shown in figure 5.

\begin{tabular}{|l|l|l|l|}
\hline $\begin{array}{l}\text { Level } \\
\text { Number }\end{array}$ & $\begin{array}{l}\text { Name of Blooms } \\
\text { Level }\end{array}$ & Required Depth of Ability & $\begin{array}{l}\text { Action Words to assess the students } \\
\text { cognitive skills }\end{array}$ \\
\hline I & Imitation & $\begin{array}{l}\text { Observe a skill and attempt to repeat it and see a } \\
\text { finished product and try to replicate it }\end{array}$ & $\begin{array}{l}\text { Attempt, copy, duplicate, imitate, mimic, } \\
\text { tracecious Competence }\end{array}$ \\
\hline II & Manipulation & $\begin{array}{l}\text { Perform the skill or produce the product in a } \\
\text { recognizable fashion following general } \\
\text { instructions }\end{array}$ & $\begin{array}{l}\text { complete, follow, perform, produce, } \\
\text { operate, carry out }\end{array}$ \\
\hline III & Precision & $\begin{array}{l}\text { Independently perform the skill with accuracy at } \\
\text { an expert level }\end{array}$ & Achieve automatically, excel, master \\
\hline IV & Articulation & $\begin{array}{l}\text { Modify the skill to fit new situations Combine } \\
\text { more than one skill }\end{array}$ & Adapt, alter, customize \\
\hline V & Naturalization & $\begin{array}{l}\text { Completion of combined skills with ease Making } \\
\text { the skill automatic }\end{array}$ & Perfect, create, design \\
\hline
\end{tabular}

Figure 5: Blooms Taxonomy at Psychomotor domain

\section{CONCLUSION}

The outcome based education is a new path in higher education institutions which starts the teaching learning methodology by keeping end product in mind. The learning outcomes are first assessed and learning objectives are set. Educational taxonomy such as one developed by bloom's et.al can be used as a fundamental developing tool for performance assessment and helps in enhancing capability and confidence in learner.

\section{REFERENCES}

[1] Lowrance, Major Christopher J. "An Efficient Teaching Technique for Engineering."

[2] Davis, Margery H. "Outcome-based education." Journal of veterinary medical education 30.3 (2003): 258-263. 
[3] Nagarathna, D. Kulenavar, and T. Shameeda Begum. "A NOVEL APPROACH FOR TEACHING SYSTEM SOFTWARE BY INTEGRATING WITH OTHER COURSES."

[4] Omar, Nazlia, et al. "Automated analysis of exam questions according to Bloom's taxonomy." Procedia-Social and Behavioral Sciences 59 (2012): 297-303.

[5] Fuller, Ursula, et al. "Developing a computer science-specific learning taxonomy." ACM SIGCSE Bulletin.Vol. 39.No. 4. ACM, 2007.
[6] Testani, Michael V., SreekanthRamakrishnan, and Donald Sobeski. "A Learning Evaluation Model for Lean Training \& Deployment Success."IIE Annual Conference.Proceedings. Institute of Industrial and Systems Engineers (IISE), 2014.

[7] Kumar, N. R., T. P. Pushpavathi, and R. Selvarani. "Dynamic Cognitive Process Application of Blooms Taxonomy for Complex Software Design in the Cognitive Domain." arXiv preprint arXiv:1002.2829 (2010).

[8] Forehand, Mary. "Bloom’s taxonomy." Emerging perspectives on learning, teaching, and technology 41 (2010): 47. 